\title{
Bacterial Aetiologies of Lower Respiratory Tract Infections among Adults in Yaoundé, Cameroon
}

\author{
Serges Tchatchouang, ${ }^{1,2,3}$ Ariane Nzouankeu, ${ }^{2}$ \\ Sebastien Kenmoe, ${ }^{1}$ Laure Ngando, ${ }^{2}$ \\ Veronique Penlap, ${ }^{3}$ Marie-Christine Fonkoua, ${ }^{2}$ \\ Eric-Walter Pefura-Yone, ${ }^{4}$ and Richard Njouom $\mathbb{D}^{1}$ \\ ${ }^{1}$ Department of Virology, Centre Pasteur of Cameroon, Member of the International Network of Pasteur Institutes, \\ P.O. Box 1274, Yaoundé, Cameroon \\ ${ }^{2}$ Department of Bacteriology, Centre Pasteur of Cameroon, Member of the International Network of Pasteur Institutes, \\ P.O. Box 1274, Yaoundé, Cameroon \\ ${ }^{3}$ Department of Biochemistry, Faculty of Science, University of Yaoundé 1, P.O. Box 812, Yaoundé, Cameroon \\ ${ }^{4}$ Department of Pneumology, Jamot Hospital, P.O. Box 4021, Yaoundé, Cameroon
}

Correspondence should be addressed to Richard Njouom; njouom@pasteur-yaounde.org

Received 23 January 2019; Revised 28 March 2019; Accepted 11 April 2019; Published 17 April 2019

Academic Editor: Roberto Cangemi

Copyright (C) 2019 Serges Tchatchouang et al. This is an open access article distributed under the Creative Commons Attribution License, which permits unrestricted use, distribution, and reproduction in any medium, provided the original work is properly cited.

Lower respiratory tract infections (LRTIs) remain a challenge in African healthcare settings and only few data are available on their aetiology in Cameroon. The purpose of this study was to access the bacterial cause of LRTIs in patients in Cameroon by two methods. Methods. Participants with LRTIs were enrolled in the referral centre for respiratory diseases in Yaoundé city and its surroundings. To detect bacteria, specimens were tested by conventional bacterial culture and a commercial reverse-transcriptase real-time polymerase chain reaction (RT-PCR) assay. One hundred forty-one adult patients with LRTIs were enrolled in the study. Among the participants, $46.8 \%$ were positive for at least one bacterium. Streptococcus pneumoniae and Haemophilus influenzae were the most detected bacteria with 14.2\% (20/141) followed by Klebsiella pneumoniae, 9.2\% (13/141), Staphylococcus aureus, 7.1\% (10/141), and Moraxella catarrhalis, 4.3\% (6/141). Bacterial coinfection accounted for 23\% (14/61) with Haemophilus influenzae being implicated in 19.7\% (12/61). The diagnostic performance of RT-PCR for bacteria detection (43.3\%) was significantly different from that of culture $(17.7 \%)(\mathrm{p}<0.001)$. Only Streptococcus pneumoniae detection was associated with empyema by RT-PCR ( $<<0.001$ ). These findings enhance understanding of bacterial aetiologies in order to improve respiratory infection management and treatment. It also highlights the need to implement molecular tools as part of the diagnosis of LRTIs.

\section{Introduction}

Lower respiratory tract infections (LRTIs) are major cause of morbidity and mortality globally [1]. In Africa, they are one of the most prevalent causes of death [2]. Particularly in sub-Saharan Africa, high case fatality ratios were reported in Somalia and Chad with 546.8 and 511.3 deaths per 100 000 inhabitants, respectively, when compared to the lowest mortality (0.65 deaths per 100000 inhabitants) registered in Finland (Europe) [2]. LRTI is a broad terminology encompassing different clinical presentations and aetiologies, which may vary according to, for example, age and season among others [3]. Overall, viruses are responsible for a large proportion of LRTIs but antibiotics are often unnecessarily prescribed for their treatment without any laboratory testing $[4,5]$ and can contribute to the emergence of antimicrobial resistance [6]. Other causes of LRTIs are bacteria: Streptococcus pneumoniae, Haemophilus influenzae, Klebsiella pneumoniae, and Staphylococcus aureus being the most common $[2,7,8]$. 
However, studies on bacterial aetiologies of LRTIs in Cameroon are limited. In addition, the few studies performed in the 90's used traditional culture methods $[9,10]$. Although culture is still considered to be the gold standard, the method has important disadvantages, such as a longer time to result, the stringent specimen collection and transport condition and the risk of inhibited growth of the pathogens due to previous antibiotic treatment $[11,12]$. As a consequence, many patients in African healthcare centres remain undiagnosed despite clinical evidence of LRTIs.

The development of nucleic acid amplification tests (NAATs) has revolutionized clinical bacteriology [13]. They are promising alternative diagnostic methods. Compared to culture, they are able to provide results within a few hours, are sensitive, and do not require viable organisms [14, 15]. Using NAATs, the viral aetiology of respiratory infections in Cameroon has been largely documented $[16,17]$; meanwhile bacterial aetiology on the other hand remains unexplored. Knowing the aetiology of LRTIs can help avoid unnecessary antibiotherapy in healthcare settings.

Our overall aim was to identify the respiratory bacteria of patients presenting with symptoms and clinical signs of LRTI at a referral centre for respiratory diseases in Yaoundé, Cameroon. Here we report on the bacteria that were detected using a commercial real-time polymerase chain reaction (RTPCR) assay in addition to traditional culture methods.

\section{Methodology}

2.1. Study Design. We conducted a prospective study among patients presenting with symptoms and clinical signs of LRTI at the pneumology department of the Jamot Hospital in Yaoundé from mid-January 2017 to mid-January 2018. This hospital is the management centre for respiratory diseases of Yaoundé city and its surroundings. LTRIs were cases of bronchitis, bronchiolitis, and pneumonia diagnosed by the physician. Adult patients who presented at least two of the following symptoms were included in the study after written informed consent was obtained: fever, cough, dyspnoea, wheezing, chest pain, or sore throat. Any prior antimicrobial treatment taken by the patient was also recorded before microbiological investigations. Patients diagnosed with pulmonary tuberculosis or with infections other than LRTIs were excluded. Sociodemographic data and clinical signs were recorded before enrolment. Empiric antibiotic therapy was not administered to patients before laboratory investigation. To guide antibiotic selection in the follow-up of participants, drug susceptibility testing was done and provided to the physicians but is not presented here.

2.2. Ethics and Consent to Participate. The study was reviewed and approved by the participating hospital and the National Research Ethics Committee of Cameroon $\left(\mathrm{N}^{\circ} 2017 / 03 / 876 / \mathrm{CE} / \mathrm{CNERSH} / \mathrm{SP}\right)$. All participants and/or the parents/legal guardians of minors provided written informed consent before enrolment. In addition, assent was sought for participants below the age of 21 year, legal age of majority in Cameroon.
2.3. Sample Collection. Clinical samples consisted of bronchoalveolar lavages (BALs) and fluids drained from pleural effusion (FPEf) or pleural empyema (FPEm) depending on the clinical and radiological presentation of the patients. Empyema was considered as collection of pus in the pleural space with secondary inflammation of the visceral and parietal pleura [18]. The samples were transported at ambient temperature and within 1 hour after collection to Centre Pasteur of Cameroon (CPC) for diagnostic testing (microscopy, bacterial culture, and anatomopathology analysis for FPEf). Upon receipt at the $\mathrm{CPC}$, the samples were divided into two aliquots. One aliquot was immediately used for bacterial culture; the other was stored in medium (universal transport medium) and kept at $-80^{\circ} \mathrm{C}$ until molecular amplification.

2.4. Bacterial Culture. According to the French REMIC guidelines, a loopful $(10 \mu \mathrm{L})$ of the sample (BAL and pleural fluids) was plated onto chocolate, $5 \%$ sheep blood agar (BA) media, and Cysteine-Lactose-Electrolyte-Deficient (CLED) plates. After inoculation, the agar plates were incubated at $37^{\circ} \mathrm{C}$, with the chocolate and $\mathrm{BA}$ agar plates in a $5 \% \mathrm{CO}_{2}$ atmosphere and the CLED agar in normal atmosphere, for 18 to 24 hours. For isolation of anaerobic bacteria, FPEm was inoculated onto 5\% sheep blood agar plates and was incubated at $37^{\circ} \mathrm{C}$ for 18 to 72 hours using GENbag anaer (bioMérieux, Marcy l'Etoile, France) to generate anaerobic growth conditions.

For pleural fluids, all growth bacteria were considered as positive irrespective of number of colonies. For BAL, protected bronchoalveolar lavage was done to avoid contamination by the oropharyngeal commensal flora. BAL fluids were serially diluted (dilutions of 1:10, 1:100, and 1:1000) and bacterial growth was defined as significant when present as $\geq$ $10^{4}$ colony forming units (cfu) per $\mathrm{mL}$.

Isolated colonies were identified using Gram staining, common biochemical tests [19], and the Vitek Compact 2 system (bioMérieux, Marcy l'Etoile, France).

2.5. RNA Extraction. RNA was extracted from all samples using the QIAamp Viral RNA Mini kit (Qiagen, Hilden, Germany), following the manufacturer's instructions. A final elution volume of $60 \mu \mathrm{L}$ of RNA was stored in $1.5 \mathrm{~mL}$ Eppendorf tubes at $-20^{\circ} \mathrm{C}$ until amplification.

2.6. Molecular Amplification. The RNAs were tested using the commercial RT-PCR assay Fast-track Diagnostics Respiratory pathogens (Fast-track Diagnostics, Junglinster, Luxembourg). This kit enabled targeting 10 bacteria: Mycoplasma pneumoniae, Chlamydophila pneumoniae, Streptococcus pneumoniae, Haemophilus influenzae type $b$, Staphylococcus aureus, Klebsiella pneumoniae, Legionella pneumophila/longbeachae, Salmonella spp., Moraxella catarrhalis, Bordetella spp. (except Bordetella parapertussis), and Haemophilus influenzae. The manufacturer's instructions were followed, briefly: a volume of $10 \mu \mathrm{L}$ of RNA was added to $15 \mu \mathrm{L}$ of fast tract master mix (buffer, primers, probes, and enzyme). Amplification was performed in an ABI PRISM 7500 RT-PCR machine (Applied Biosystems, Foster City, CA, USA). An internal control was added to all samples to 
TABLE 1: Sociodemographic and clinical characteristics of the study population.

\begin{tabular}{|c|c|c|}
\hline Study population & Total $(n=141)$ & Positive bacterial culture $(n=25)$ \\
\hline \multicolumn{3}{|l|}{ Age } \\
\hline Median age in years (IQR) & $50(34.7-62.1)$ & $48(32.9-62.8)$ \\
\hline 18-35 years (young adults) & $37(26.2)$ & $8(32)$ \\
\hline 36-55 years (middle-aged adults) & $56(39.7)$ & $9(36)$ \\
\hline$>55$ years (old adults) & $48(34)$ & $8(32)$ \\
\hline \multicolumn{3}{|l|}{ Gender } \\
\hline Males & $90(63.8)$ & $16(64)$ \\
\hline Females & $51(36.2)$ & $9(36)$ \\
\hline Smoking habit & $30(21.3)$ & $2(8)$ \\
\hline Duration of symptoms (days) & $45(21-90)$ & $45(37.5-67.7)$ \\
\hline \multicolumn{3}{|l|}{ Clinical signs } \\
\hline Cough & $123(87.2)$ & $22(88)$ \\
\hline Dyspnoea & $121(85.8)$ & $22(88)$ \\
\hline Breathlessness & $117(83)$ & $20(80)$ \\
\hline Asthenia & $107(75.9)$ & $19(76)$ \\
\hline Fever & $90(63.8)$ & $16(64)$ \\
\hline Chest pain & $85(60.3)$ & $13(52)$ \\
\hline Myalgia & $60(42.6)$ & $5(20)$ \\
\hline Arthralgia & $31(22)$ & $5(20)$ \\
\hline Headaches & $24(17)$ & $1(4)$ \\
\hline Sore throat & $14(9.9)$ & $2(8)$ \\
\hline Vomiting & $11(7.8)$ & $2(8)$ \\
\hline Diarrhea & $10(7.1)$ & 0 \\
\hline Rhinorrhea & $7(5)$ & $1(4)$ \\
\hline Conjunctivitis & $2(1.4)$ & 0 \\
\hline
\end{tabular}

Data are number and percentage in brackets; IQR: interquartile range; $n$ : number.

ensure validity of the assay. Positive and negative controls were included in each experiment.

2.7. Statistical Analysis. Data were analysed using the Statistical Package for Social Sciences software (version 22.0, SPSS Inc., Chicago, IL, USA). Distribution of categorical variables was compared using the chi-square or Fisher's exact tests as appropriate. Independent $t$-test was done for mean comparison between groups. Results of bacterial detection by culture and RT-PCR were compared using the McNemar test. The significance level was set at 0.05 .

\section{Results}

3.1. Study Population. Overall, a total of 141 patients were enrolled; the male/female sex ratio was 1.8. The patients' age ranged from 18 to 94 years with a median age of 50 years (interquartile range: 34.7-62.1). No mean age difference was noticed among males and females $(p=0.786)$. The sociodemographic and clinical characteristics of the patients are summarised in Table 1 . The most predominant symptoms were cough $(87.2 \%)$, dyspnoea $(85.8 \%)$, breathlessness $(83 \%)$, asthenia $(75.9 \%)$, fever $(63.8 \%)$, chest pain $(60.3 \%)$, and myalgia (42.6\%). Among the type of specimens collected, FPEf accounted for $47.1 \%$ (67/141), BAL for $28.4 \%$ (40/141), and FPEm for $24.1 \%(34 / 141)$. The majority of patients
(76.6\%) had already taken antimicrobials (beta-lactams, sulfonamides, aminoglycoside, macrolides, and quinolones) before the enrolment.

3.2. Bacterial Detection. Bacteria were detected in $17.7 \%$ $(25 / 141)$ and $43.3 \%(61 / 141)$ of the samples using traditional culture and RT-PCR, respectively $(\mathrm{p}<0.001)$. Combining both techniques, an aetiological bacterial agent was detected in $46.8 \%(66 / 141)$ of the samples. Both methods detected more frequently $S$. pneumoniae ( $14.2 \%$ by RT-PCR versus $5.7 \%$ by culture), $H$. influenzae (14.2\% by RT-PCR versus $3.5 \%$ by culture), and K. pneumoniae ( $9.2 \%$ by RT-PCR versus $3.5 \%$ by culture).

As the BALs were sampled aseptically, we obtained 14 bacterial growths out of the 40 plated. One culture exhibited two bacterial species out of 14 . The BAL cultures for which the less bacterial growth was noted had $10^{4} \mathrm{cfu} / \mathrm{mL}$. For pleural fluids, the bacterial growth ranged from 7 to more than $10^{6}$ $\mathrm{cfu} / \mathrm{mL}$.

There was no association between clinical symptoms of inclusion and bacterial detection methods $(p>0.05)$. There was an association between myalgia and bacterial culture $(\mathrm{p}=$ 0.014). There was no difference for bacterial detection among patients under antibiotics prior to the diagnosis and those who were not $(\mathrm{p}=0.757)$. Results according to sample type and method are presented in Table 2. S. pneumoniae was 


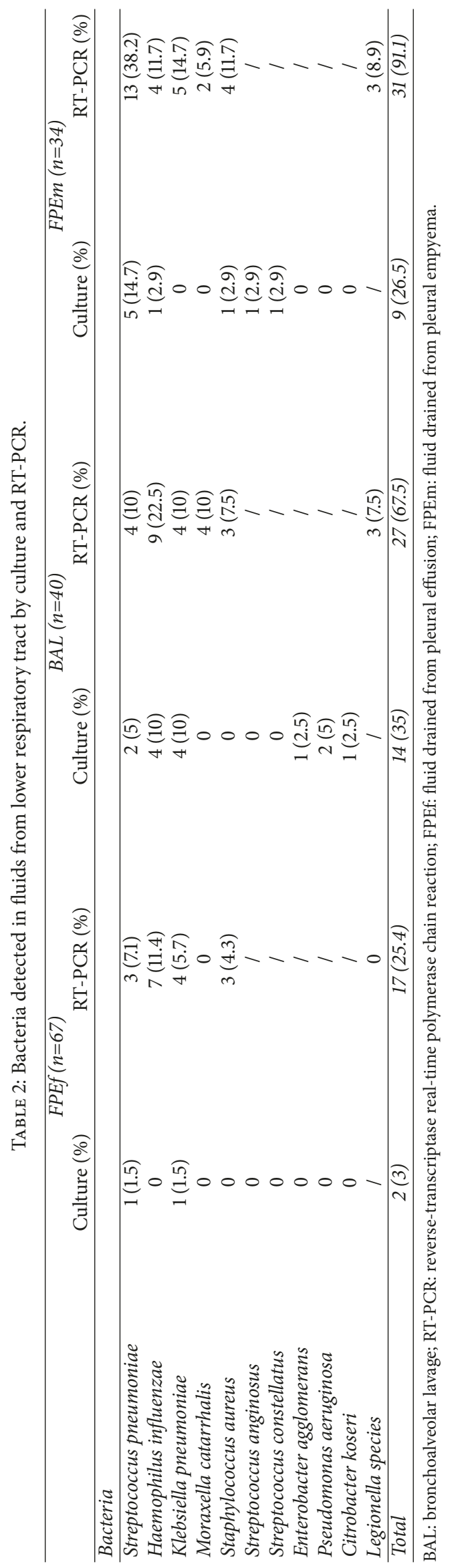


TABLE 3: Level of coinfections in lower respiratory tract by RT-PCR.

\begin{tabular}{|c|c|c|c|}
\hline Infection level & Pathogens & Number & $\begin{array}{l}\text { Clinical } \\
\text { samples }\end{array}$ \\
\hline \multirow{3}{*}{$\begin{array}{l}\text { Double bacterial } \\
\text { infection }\end{array}$} & Haemophilus influenzae + Legionella species & 1 & FPEm \\
\hline & $\begin{array}{c}\text { Haemophilus influenzae }+ \text { Streptococcus } \\
\text { pneumoniae }\end{array}$ & 3 & $\begin{array}{l}2 \mathrm{BAL}+1 \\
\text { FPEm }\end{array}$ \\
\hline & Streptococcus pneumoniae + Klebsiella pneumoniae & 2 & FPEm \\
\hline \multirow{5}{*}{$\begin{array}{l}\text { Triple bacterial } \\
\text { infection }\end{array}$} & Haemophilus influenzae + Staphylococcus aureus & 3 & FPEf, 2 BAL \\
\hline & Haemophilus influenzae + Klebsiella pneumoniae & 2 & $\mathrm{BAL}+\mathrm{FPEf}$ \\
\hline & $\begin{array}{c}\text { Haemophilus influenzae + Staphylococcus aureus } \\
\text { +Klebsiella pneumoniae }\end{array}$ & 1 & FPEm \\
\hline & $\begin{array}{c}\text { Haemophilus influenzae + Legionella species }+ \\
\text { Klebsiella pneumonia }\end{array}$ & 1 & BAL \\
\hline & $\begin{array}{c}\text { Haemophilus influenzae }+ \text { Legionella species }+ \\
\text { Moraxella catarrhalis }\end{array}$ & 1 & FPEm \\
\hline
\end{tabular}

RT-PCR: reverse-transcriptase real-time polymerase chain reaction; BAL: bronchoalveolar lavage; FPEf: fluid drained from pleural effusion; FPEm: fluid drained from pleural empyema.

significantly more detected in FPEm $(\mathrm{p}<0.001)$ compared to the other sample types.

3.3. Coinfections. Multiple bacteria or bacterial coinfections were detected in a total of 14/61 (23\%) specimens using RTPCR. Only one case of coinfection was reported with culture: Pseudomonas aeruginosa and Citrobacter koseri (4\%; 1/25) in BAL. Table 3 shows the different coinfections obtained according to the clinical sample.

\section{Discussion}

The diagnosis and management of respiratory tract infections are great challenges in Africa due to the socioeconomic burden and limited access to good healthcare and hospitals. In order to formulate adequate guideline for the management of LRTIs, including diagnosis and treatment, data on the aetiology of the LRTIs should be obtained. This study focused on establishing the bacterial aetiology of LRTIs following diagnostic tools and type of clinical samples. One hundred and forty-one clinical samples from patients presenting symptoms of LRTIs were subjected to bacterial investigations using traditional culture and RT-PCR.

At least one bacterium could be detected in $46.8 \%$ of the 141 patients clinically diagnosed with LRTIs. This prevalence is similar to $45.2 \%$ found in Enugu State, Nigeria [20], but higher than the $24 \%$ reported in Tunisia [21]. Using the same diagnostic approach, prevalence of $77 \%$ and $85.7 \%$ was reported in Gambia and in Osun State, Nigeria, respectively $[22,23]$. The prevalence rates may be explained by the differences in study designs and geographic areas. Indeed, the spread of respiratory infections varies between populations and countries, depending on difference in geography, climate, and socioeconomic conditions [2427]. In addition, we reported the bacterial aetiology of LRTIs in adults, whereas most studies included only children. The lower prevalence rate compared to Gambia and Nigeria might also be explained by the high percentage $(76.6 \%)$ of patients who used antibiotics before enrolment.
S. pneumoniae was the leading pathogen of LRTIs followed by $H$. influenzae and $K$. pneumoniae. S. pneumoniae was also found to be the main cause of LRTIs in a study in Malawi [28] and Tunisia [21]. However, other studies in Nigeria, which is a neighboring country of Cameroon, reported $K$. pneumoniae as the most detected pathogen [8, 20] in LRTIs or $S$. aureus in Tunisia [29]. S. pneumoniae remains an important pathogen in LRTIs even with the introduction of 13-valent pneumococcal conjugate vaccine [30]. This suggests that further investigations are needed for vaccine impact. Conversely, no $H$. influenzae type b was observed. Although S. pneumoniae, $H$. influenzae, and $K$. pneumoniae were the key bacteria, there was a remarkable variation in distribution of these etiologic agents between clinical samples.

We observed an association between bacterial detection and type of clinical sample. The bacterial detection rate was the lowest in FPEf compared to the other clinical samples. The frequency of bacterial detection in FPEf (3\% by culture) was as low as the one observed in Spain, where 7\% (14/191) of fluids from uncomplicated parapneumonic pleural effusions were culture-positive [31]. The low detection level could be due to the fact that $80.6 \%$ of FPEf were from patients undergoing an antimicrobial treatment.

In FPEm, the bacterial detection rate by culture $(26.5 \%)$ was low compared to previous results obtained in the Jamot Hospital (Yaoundé, Cameroon) 8 years ago, where the bacterial detection rate was $53.7 \%$ [32] and also compared to a study in Lleida Spain, reporting a culture positivity rate of $66 \%$ [31]. But our bacterial detection rate in FPEm was higher compared to the one obtained in San Sebastian, Spain, where only $10 \%$ of bacteria-positive FPEm was detected by culture between January 2005 and December 2012 [33]. Also in the study performed in San Sebastian, the use of antibiotics prior to bacteriological investigations was high (81.7\%). However, the study performed in Lleida did not report on the prior use of antibiotics. Most bacterial detections were in FPEm and we hypothesize that this could be due to the nutrientrich medium of FPEm supporting the growth of pathogenic 
bacteria such as S. pneumoniae strains. This may be one of the reasons why pneumococci are a common bacterial cause of empyema. Thus, the high density and persistent growth of S. pneumoniae in pleural fluid highlight the importance of draining infected effusions [34].

We found $H$. influenzae to be the key pathogen in BAL, which is different from what has been observed in lung aspirates of Malawian and Gambian children with $S$. pneumoniae [22, 35]. Our result in BAL is also different from the ones in Korean adults with methicillin-resistant $S$. aureus [36] as the most frequently isolated bacterium. Overall, bacterial profiles from BAL vary among studies [37].

The RT-PCR increased the yield of bacteria detection by $25.5 \%$. As previously reported [33], the use of molecular tool has greatly improved microbial diagnosis of LRTIs. In the present study, only 25 positive cultures were obtained among the 141 patients. Concordant with a recent study conducted in Sweden [38], using the RT-PCR, we were able to detect the noncultivable and fastidious pathogen Legionella species which is overlooked by routine standard culture. Rapid detection of uncommon pathogens from LRTI samples by molecular tool might be important in the clinical routine. Almost all coinfections were detected using RT-PCR. Bacterial coinfection rate was near to the $18.9 \%$ of inpatients with nonresponding community-acquired pneumonia in Belgium [39]. This finding suggests that molecular assay is the most useful method to detect coinfections representing near-past and current infections.

Limitations. Antibiotic treatment prior to the diagnosis and delay of patients could be biases for real pathogen frequencies reported in this study.

\section{Conclusion}

Bacterial aetiology was more reported in cases of LRTI with empyema. S. pneumoniae and $H$. influenzae were the most commonly detected bacteria. The molecular tool used during investigation detected significantly more bacteria than traditional culture and may be an additional helpful tool for diagnosis of LRTIs. Nevertheless, control of antibiotic use and early diagnosis are crucial when managing LRTIs.

\section{Data Availability}

The data used to support the findings of this study are available from the corresponding author upon request.

\section{Conflicts of Interest}

The authors declare that there are no conflicts of interest regarding the publication of this paper.

\section{Acknowledgments}

This work was supported by the United States Department of Health and Human Services [Grant no. 6 DESP060001-0101] via the International Network of Pasteur Institutes. The authors' gratitude goes towards participants. They appreciate the collaboration of the Yaoundé Jamot Hospital staff.

\section{References}

[1] C. J. L. Murray and A. D. Lopez, "Measuring the global burden of disease," The New England Journal of Medicine, vol. 369, no. 5, pp. 448-457, 2013.

[2] "Estimates of the global, regional, and national morbidity, mortality, and aetiologies of lower respiratory tract infections in 195 countries: a systematic analysis for the Global Burden of Disease Study 2015," The Lancet Infectious Diseases, vol. 17, no. 11, pp. 1133-1161, 2015.

[3] S. Khan, P. Singh, M. Ansari, and K. Gurung, "Bacteria etiological agents causing lower respiratory tract infections in the western part of Nepal," Ibnosina Journal of Medicine and Biomedical Sciences, vol. 6, no. 1, pp. 3-8, 2014.

[4] L. Ren, Z. Xiang, L. Guo, and J. Wang, "Viral infections of the lower respiratory tract," Current Infectious Disease Reports, vol. 14, no. 3, pp. 284-291, 2012.

[5] A. T. Pavia, "Viral infections of the lower respiratory tract: Old viruses, new viruses, and the role of diagnosis," Clinical Infectious Diseases, vol. 52, no. 4, pp. S284-S289, 2011.

[6] A. S. Ouedraogo, H. Jean Pierre, A. L. Bañuls, R. Ouédraogo, and S. Godreuil, "Emergence and spread of antibiotic resistance in West Africa: contributing factors and threat assessment," Medecine et Sante Tropicales, vol. 27, no. 2, pp. 147-154, 2017.

[7] M. Uzoamaka, O. Ngozi, O. S. Johnbull, and O. Martin, "Bacterial etiology of lower respiratory tract infections and their antimicrobial susceptibility," The American Journal of the Medical Sciences, vol. 354, no. 5, p. 471, 2017.

[8] C. A. Egbe, C. Ndiokwere, and R. Omoregie, "Microbiology of lower respiratory tract infections in Benin city, Nigeria," Malaysian Journal of Medical Sciences, vol. 18, no. 2, pp. 27-31, 2011.

[9] S. Koulla-Shiro, C. Kuaban, and L. Belec, "Acute communityacquired bacterial pneumonia in human immunodeficiency virus (HIV) infected and non-HIV-infected adult patients in Cameroon: Aetiology and outcome," Tubercle and Lung Disease, vol. 77, no. 1, pp. 47-51, 1996.

[10] S. Koulla-Shiro, C. Kuaban, and L. Bélec, "Microbial etiology of acute community-acquired pneumonia in adult hospitalized patients in Yaounde-Cameroon," Clinical Microbiology and Infection, vol. 3, no. 2, pp. 180-186, 1997.

[11] D. J. Cook, J. M. Fitzgerald, G. H. Guyatt, and S. Walter, "Evaluation of the protected brush catheter and bronchoalveolar lavage in the diagnosis of nosocomial pneumonia," Journal of Intensive Care Medicine, vol. 6, no. 4, pp. 196-205, 1991.

[12] "Guidelines for the management of adults with hospitalacquired, ventilator-associated, and healthcare-associated pneumonia," American Journal of Respiratory and Critical Care Medicine, vol. 171, no. 4, pp. 388-416, 2005.

[13] K. B. Laupland and L. Valiquette, "The changing culture of the microbiology laboratory," The Canadian Journal of Infectious Diseases \& Medical Microbiology, vol. 24, no. 3, pp. 125-128, 2013.

[14] A. Endimiani, K. M. Hujer, A. M. Hujer et al., "Are we ready for novel detection methods to treat respiratory pathogens in hospital-acquired pneumonia?" Clinical Infectious Diseases, vol. 52, supplement 4, pp. S373-S383, 2011. 
[15] M. Lung and G. Codina, "Molecular diagnosis in HAP/VAP," Current Opinion in Critical Care, vol. 18, no. 5, pp. 487-494, 2012.

[16] S. Kenmoe, P. Tchendjou, M.-A. Vernet et al., "Viral etiology of severe acute respiratory infections in hospitalized children in Cameroon, 2011-2013," Influenza and Other Respiratory Viruses, vol. 10, no. 5, pp. 386-393, 2016.

[17] R. Njouom, E. L. Yekwa, P. Cappy, A. Vabret, P. Boisier, and D. Rousset, "Viral etiology of influenza-like illnesses in Cameroon, January-December 2009," The Journal of Infectious Diseases, vol. 206, supplement 1, pp. S29-S35, 2012.

[18] M. Ried, J. Graml, C. Groer, H.-S. Hofmann, and Z. Sziklavari, "Para- and postpneumonic pleural empyema: current treatment strategies in children and adults," Zentralblatt fur Chirurgie, vol. 140, Supplement 1, pp. S22-S28, 2015.

[19] W. C. Winn, S. D. Allen, A. Stephen et al., Koneman's Color Atlas and Textbook of Diagnostic Microbiology, 6th edition, 2006.

[20] M. Uzoamaka, O. Ngozi, O. S. Johnbull, and O. Martin, "Bacterial etiology of lower respiratory tract infections and their antimicrobial susceptibility," The American Journal of the Medical Sciences, vol. 354, no. 5, pp. 471-475, 2017.

[21] M. Fekih Hassen, A. Ben Haj Khalifa, N. Tilouche et al., "Severe community-acquired pneumonia admitted at the intensive care unit: Main clinical and bacteriological features and prognostic factors: A Tunisian experience," Revue de Pneumologie Clinique, vol. 70, no. 5, pp. 253-259, 2014.

[22] S. R. C. Howie, G. A. J. Morris, R. Tokarz et al., "Etiology of severe childhood pneumonia in the Gambia, West Africa, determined by conventional and molecular microbiological analyses of lung and pleural aspirate samples," Clinical Infectious Diseases, vol. 59, no. 5, pp. 682-685, 2014.

[23] B. P. Kuti and O. A. Oyelami, "Risk factors for parapneumonic effusions among children admitted with communityacquired pneumonia at a tertiary hospital in south-west Nigeria," African Journal of Respiratory Medicine, vol. 10, no. 1, pp. 26-34, 2014.

[24] T. B. Kwofie, Y. A. Anane, B. Nkrumah, A. Annan, S. B. Nguah, and M. Owusu, "Respiratory viruses in children hospitalized for acute lower respiratory tract infection in Ghana," Virology Journal, vol. 9, article no. 78, 2012.

[25] X. Huo, Y. Qin, X. Qi et al., "Surveillance of 16 respiratory viruses in patients with influenza-like illness in Nanjing, China," Journal of Medical Virology, vol. 84, no. 12, pp. 1980-1984, 2012.

[26] J. del Valle Mendoza, A. Cornejo-Tapia, P. Weilg et al., "Incidence of respiratory viruses in peruvian children with acute respiratory infections," Journal of Medical Virology, vol. 87, no. 6, pp. 917-924, 2015.

[27] B. Cui, D. Zhang, H. Pan et al., "Viral aetiology of acute respiratory infections among children and associated meteorological factors in southern China," BMC Infectious Diseases, vol. 15, p. 124, 2015.

[28] T. K. Hartung, D. Chimbayo, J. J. G. van Oosterhout et al., "Etiology of suspected pneumonia in adults admitted to a highdependency unit in Blantyre, Malawi," The American Journal of Tropical Medicine and Hygiene, vol. 85, no. 1, pp. 105-112, 2011.

[29] S. Hamouda, K. Chraiet, F. Khalsi et al., "Community-acquired pleuropneumonia in children: Bacteriological and therapeutic challenges," La Tunisie Médicale, vol. 94, no. 4, pp. 290-297, 2016.

[30] L. F. Pittet and K. Posfay-Barbe, "Pneumococcal vaccines for children: A global public health priority," Clinical Microbiology and Infection, vol. 18, no. 5, pp. 25-36, 2012.
[31] J. M. Porcel, A. Esquerda, M. Vives, and S. Bielsa, "Etiology of Pleural Effusions: Analysis of More than 3,000 Consecutive Thoracenteses," Archivos de Bronconeumología, vol. 50, no. 5, pp. 161-165, 2014.

[32] E. W. Yone Pefura, C. Kuaban, S. Leonie, and E. Afane Ze, "Nontuberculous purulent pleural effusion in adults in Yaounde, Cameroon," Medecine et Sante Tropicales, vol. 22, no. 1, pp. 3539, 2012.

[33] J. M. Marimón, M. Morales, G. Cilla, D. Vicente, and E. Pérez-Trallero, "Detection of bacteria and viruses in the pleural effusion of children and adults with community-acquired pneumonia," Future Microbiology, vol. 10, no. 6, pp. 909-915, 2015.

[34] N. D. Popowicz, S. M. Lansley, H. M. Cheah et al., "Human pleural fluid is a potent growth medium for Streptococcus pneumoniae," PLoS ONE, vol. 12, no. 11, Article ID e0188833, 2017.

[35] E. D. Carrol, L. A. Mankhambo, M. Guiver et al., "PCR improves diagnostic yield from lung aspiration in malawian children with radiologically confirmed pneumonia," PLoS ONE, vol. 6, no. 6, Article ID e21042, 2011.

[36] E. S. Kim, E.-C. Kim, S.-M. Lee et al., "Bacterial yield from quantitative cultures of bronchoalveolar lavage fluid in patients with pneumonia on antimicrobial therapy," Korean Journal of Internal Medicine, vol. 27, no. 2, pp. 156-162, 2012.

[37] M. El-Shabrawy and R. H. EL-Sokkary, "Role of fiberoptic bronchoscopy and BAL in assessment of the patients with nonresponding pneumonia," Egyptian Journal of Chest Diseases and Tuberculosis, vol. 65, no. 3, pp. 613-620, 2016.

[38] M. Ullberg, P. Lüthje, P. Mölling, K. Strålin, and V. Özenci, "Broad-range detection of microorganisms directly from bronchoalveolar lavage specimens by PCR/electrospray ionizationmass spectrometry," PLoS ONE, vol. 12, no. 1, Article ID e0170033, 2017.

[39] I. De Schutter, E. De Wachter, F. Crokaert et al., "Microbiology of bronchoalveolar lavage fluid in children with acute nonresponding or recurrent community-acquired pneumonia: Identification of nontypeable haemophilus influenzae as a major pathogen," Clinical Infectious Diseases, vol. 52, no. 12, pp. 1437-1444, 2011. 


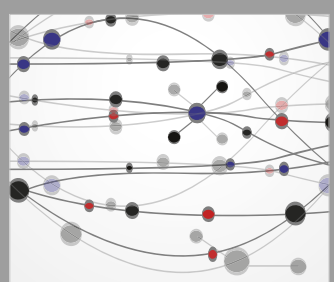

The Scientific World Journal
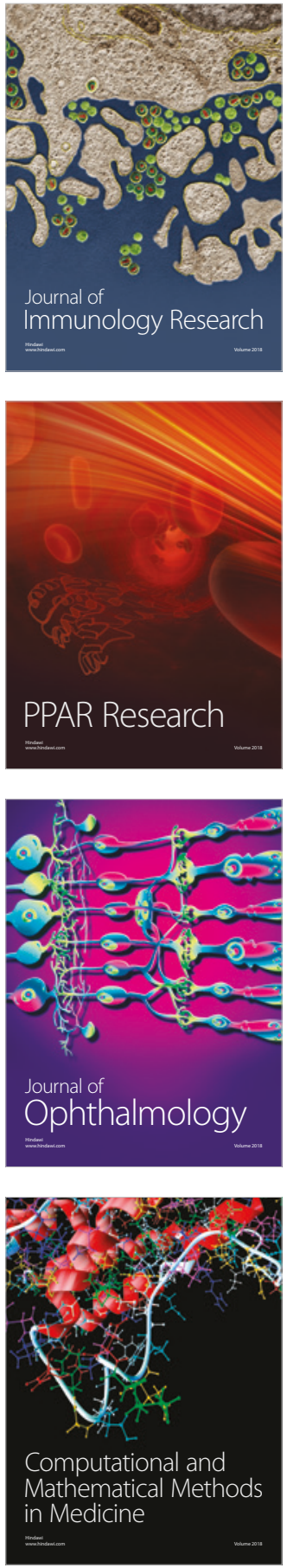

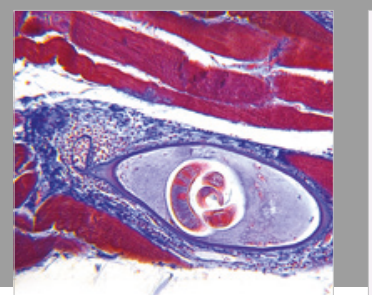

Gastroenterology Research and Practice

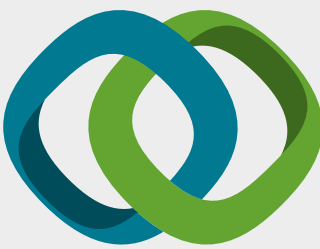

\section{Hindawi}

Submit your manuscripts at

www.hindawi.com
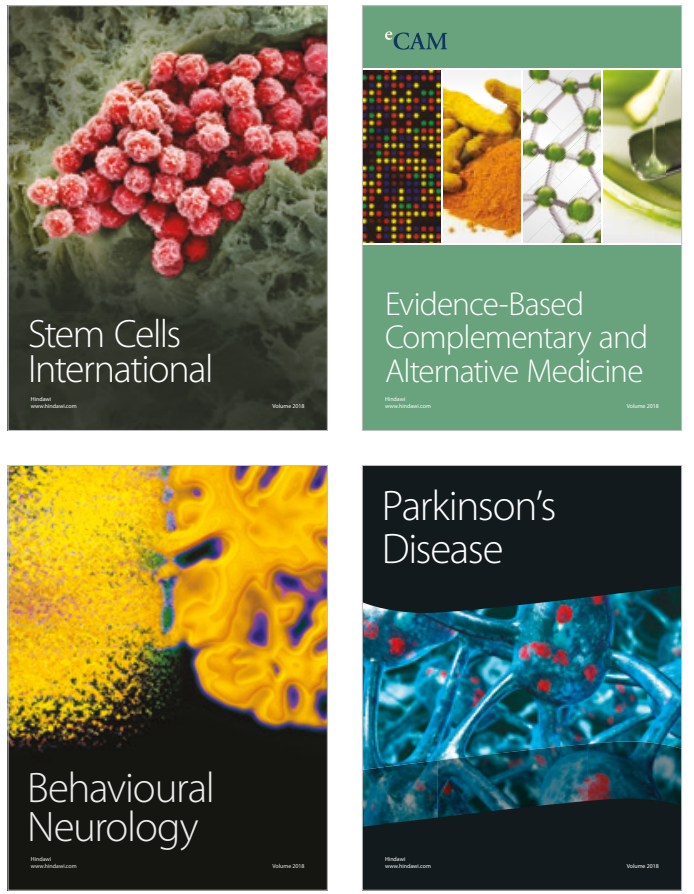

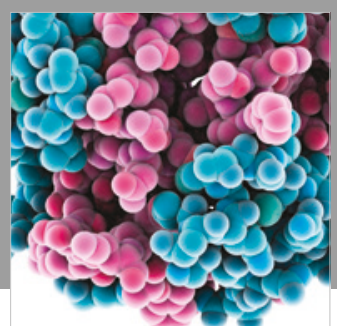

ournal of

Diabetes Research

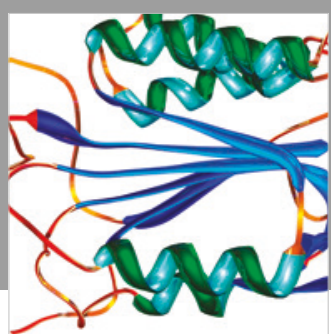

Disease Markers
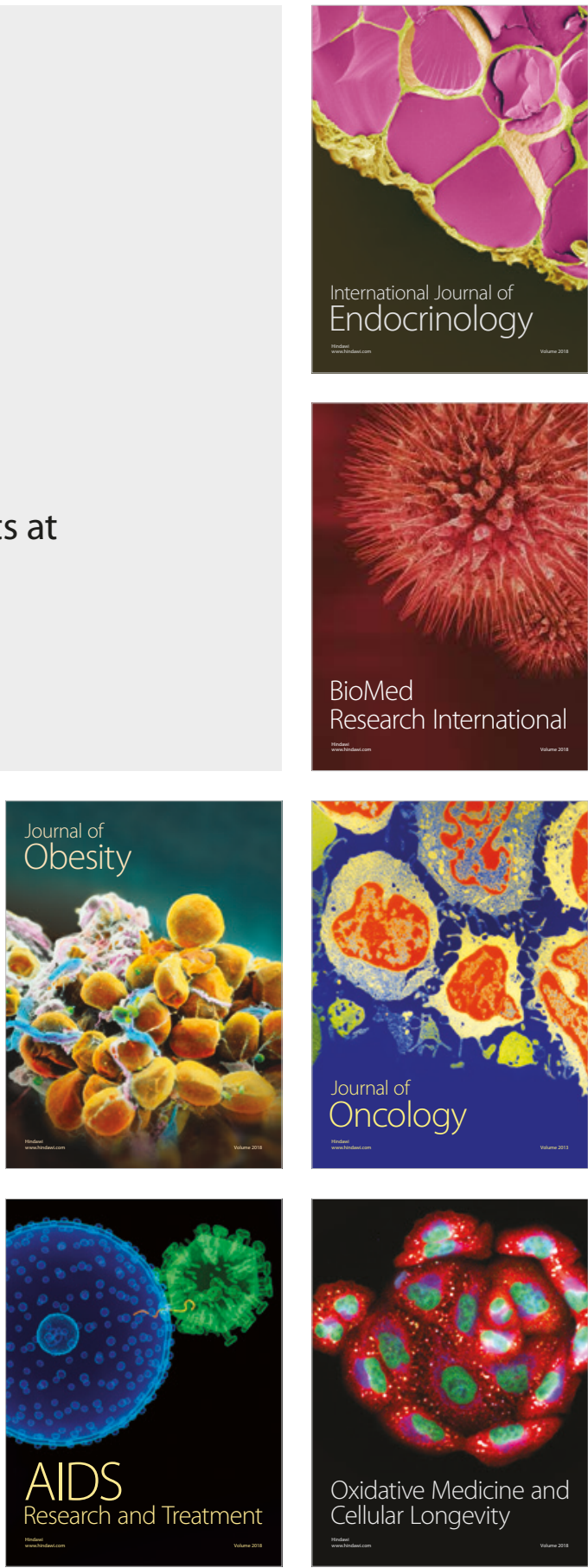